\title{
The Shape of Equality: Discursive Deployments during the Section 28 Repeal in
}

\section{Scotland.}

\author{
Abstract \\ In this article, I focus on conceptualisations of equality in the discourses deployed in \\ the campaign to repeal of Section 28 in Scotland. I use the Parliamentary debates and \\ two newspapers: The Daily Record, which supported the campaign to Keep the \\ Clause, The Guardian, which supported repeal, to exemplify the different discursive \\ articulations around equality and citizenship. I suggest that the Scottish example \\ provides further evidence of the ways in which liberalism naturalises heterosexuality \\ as the standard for citizenship and thus bequeaths a hierarchy of 'equality' and \\ citizenship in the realm of sexuality, wherein lesbian and gay citizenship is either \\ rendered invalid or characterised as 'special rights'. However, within the narrow \\ confines of the Parliamentary debates, more expansive and differentiated notions of \\ citizenship and equality are evident. Whilst I conclude that the 'shape' of equality \\ achieved through the repeal has been moulded to support institutionalised \\ heterosexuality - with Section 28 replaced by statutory guidelines on sex education \\ which advocate marriage - I also suggest equality is contested, both through the \\ recognition of transformations in heterosexual family forms and the appeal to non- \\ discrimination as a democratic principle. It is possible, therefore, that current \\ destabilisations of the heterosexual social order simultaneously destabilises the \\ precepts of liberal democracy.
}

Key words: Section 28, Scotland, homosexuality, equality, citizenship, liberalism, democracy. 
The Shape of Equality: Discursive Deployments during the Section 28 Repeal in

\section{Scotland.}

Section 28 (called Section 2a in Scotland) was introduced in 1986 as part of a local government bill and became law in the UK in 1988. It prohibited the promotion of homosexuality as a 'pretended family relationship' in all aspects of local authority responsibility, including education. Although its effects are disputed, it has certainly become a symbolic manifestation of the discrimination against lesbians and gays (Epstein, 2000, Rheinhold 1994) which is central to the traditionalist familial ideology of the New Right, both in Britain and the USA (Durham 1991, Weeks 1989). Indeed, it served to both mobilise lesbian and gay politics in Britain at its introduction, and provide a durable backdrop for debates about family diversity, equality, citizenship and human rights thereafter. It remains on the statute books in England and Wales but the devolved Scottish Parliament has had control over local government matters since its inception in 1999. In June 2000, after a lengthy and controversial Parliamentary and public debate, Section 28 was repealed in Scotland but replaced with statutory requirements to promote marriage in educational settings. In this article, I analyse the discourses on sexual identity and equality which were deployed by pro- and anti-repeal factions during the six month period of the campaign.

My first aim is to contribute to the recent literature which interrogates the second wave of gender and sexual politics in liberal democratic systems; focusing in particular on political and civil rights, citizenship, the individualism of liberalism and consequent conditions of equality (Brickell 2001, Phelan, 2001, Johnson 2002, Richardson 2000, Rahman 2000). The discourses apparent in the Section 28 repeal 
provide further examples of the ways in which rights for homosexuals were delegitimised and liberal individualism was deployed to limit the scope of these rights and thus the scope of equality. However, they also provide examples of how notions of social justice and diversity are beginning to permeate mainstream political discourses on sexuality. My second aim is to explore these tensions in the shaping of equality during the repeal campaign.

Previous interventions, from a variety of social science perspectives, have emphasised both the necessary and problematic strategy of pursuing rights as a route to a condition of equality in gender and sexuality. Equality is the ultimate aim, often conceptualised as conditions of equal citizenship across civil, political and social (Phillips 1993, Walby 1994), sometimes specifically extended to 'cultural' (Richardson 1998) and 'initmate' (Plummer 1995) citizenship in relation to sexuality. There has also been a conceptualisation of equality as 'recognition' (Fraser 1998), both of previous marginalisation and of contemporary differences. Across this wealth of research, there is a consistent line of argument that, regardless of what ultimate condition of equality is assumed, the narrow focus of indivdualised liberal rights makes it difficult to argue for wider social change.

Feminist political and social theorists have demonstrated that social and material inequalities for women have persisted after the attainment of civil and political rights (Walby 1994) because the formal equality demanded by a rigorous application of liberal principles simultaneously demands an acceptance that those principles and their attendant rights are applied to the individual: 
If we consider liberal democracy as an amalgam of certain key principles from the liberal and democratic traditions, what it takes from liberalism is an abstract individualism which may note the difference between us but says that these differences should not count. At its best, this is a statement of profound egalitarianism that offers all citizens the same legal and political rights, regardless of their wealth, status, race or sex. At its worst, it refuses the pertinence of continuing difference and inequality, pretending for the purposes of argument that we are all of us basically the same.

(Philips 1993: 114)

This individualist tendency has come under scrutiny from both feminist and, more recently, lesbigay/queer political theorists because it 'obscures oppression.' (Young 1994: 718). Formal political equality, expressed as individual/human rights, ignores the social relationships of subordination/domination (Brickell 2001: 213, Rahman 2000: 164) which construct inequalities between social groups and which then create problems for specific individual humans precisely because they are located within these social groups. A major achievement of contemporary interrogations of sexual politics has therefore been to demonstrate the many ways in which liberal democratic principles and practices take the institutionalised privilege of heterosexuality for granted as the default setting for political, civil (Brickell 2001, Johnson 2002, Stychin 1998) and social rights (Carabine 1996, Richardson 1998, 2000). A consequence of these arguments has been a diverse critique of the quality of 'equality' bequeathed within these political systems, with a fairly consistent implication that both the technologies (human rights, legal and social policies) and values (hetero-moral and sexual essentialist) of liberal democracy must be challenged, expanded and 
reformulated to achieve effective conditions of 'equality' or citizenship in the realm of sexuality.

The analysis below supports the arguments above: equal rights/human rights discourses were largely overwhelmed by the negative construction of homosexuality and the construction of children as vulnerable. The naturalised incorporation of heterosexual privilege and the hetero-moral order are evident within the liberal discourses deployed during the repeal campaign, as are attempts to characterise the repeal as a move beyond equality to 'licence' for 'special rights'. The quality of equality achieved is also suspect: a condition in which one policy is removed but another imposed - the statutory requirement to discuss marriage. However, there are also examples which demonstrate that the discursive conceptualisation of equality is severely contested; limited by liberalism on the one hand but expanded and extended on the other by the appeal to notions of social justice and respect for differences. I focus therefore not simply on the quality of equality as an outcome or condition, but on the discursive formations of equality - how it is conceptualised in the political and cultural realm as a resource for political progress and the articulation of lived experience. My second aim is therefore to explore these complexities and contradictions within democratic discourses to better understand the form and content of equality - the 'shape' of equality, if you will - as a cultural and political resource in contemporary sexual politics.

\section{Locating the Section 28 debate in Scotland}

My focus on Scotland is dictated by the recent establishment of a devolved parliament which has control over some areas relevant to lesbians and gays, most visibly Section $28^{1}$. The United Kingdom parliament retains control over this policy 
for England and Wales and, moreover, has UK wide authority over other issues which affect lesbians and gays, such as the age of consent for gay men, most social policy and immigration policy. Furthermore, although the European Union has already intervened in matters sexual through both European Court of Justice and European Court of Human Rights rulings, and we have yet to witness the full ramifications of the incorporation of the European Charter of Human Rights into UK and Scottish domestic law. ${ }^{2}$ Given the intersections of competing, complementary and contradictory social and political agendas, and the particular salience of the Section 28 repeal in Scotland, Scottish society is a richly complex setting in which to investigate the contemporary political progress and social significance of sexuality which, as Phelan reminds us, is an urgent issue in Western democracies:

In the last fifteen years sexuality has become central to modern, politics, especially in the United States and Great Britain, to a previously unimaginable degree. The religious Right uses the spectre of homosexual power in order to recruit and spur their armies to battle modernity. Overlapping battalions attack women's reproductive freedom - and increasingly endorse murder - in the name of life.

(Phelan 1997:1)

Although Phelan is referring primarily to the USA, we can see clear parallels with the UK. The 1980s saw the introduction of Section 28 and both the 1980s and 1990s saw the identification of HIV and AIDS with homosexuality (Altman 1986, Durham 1991). In Scotland we have seen an alliance of Churches (most prominently the late Cardinal Winning - the head of the Catholic Church) and the Keep the Clause campaign which has framed its arguments in terms of the naturalness of 
heterosexuality and the sanctity of marriage. Even after the repeal of Section 28, concerns over sexuality remained centre stage. The Scotsman reported that a pro-life group, Precious Life Scotland, has begun a new campaign called Parent Truth involving pro-life groups, the Family Action Movement and the Multi-Faith Coalition which is focused on the Scottish Executive's proposals for increasing teenage access to sex education information and clinics: "Parent Truth said last night that it would be a 'new rallying point' for those opposed to the repeal of Section 28 , which prohibited the promotion of homosexuality in schools." (The Scotsman, lead story, Saturday 11th November 2000). Although their promised campaign during the second elections for the Scottish Parliament (May 2003) failed to make any media or political impact, the proposed civil marriage bill for lesbians and gays (put forward by the newly elected Green MSP, Patrick Harvie) promises a return to the controversies of diversity which homosexual equality generates.

It is obvious that the story of lesbian and gay issues during the time of devolution cannot be characterised simply as another chapter in the extension of universal human rights to a minority group. The public acknowledgement of lesbians and gays as equal citizens is a matter of fierce controversy and the extension of formal legislation or policy to equalise under the law is faced with extreme resistance and constant setbacks. Such a trajectory of lesbian and gay political issues can only be grasped with a sociological understanding of the meaning and significance of homosexuality within our society. Whilst the removal of Section 2a in Scotland appears to be a victory for equal rights, the repeal does not provide any new rights or promote any particular liberties: it simply removes a piece of legislation which only applied to homosexuality. Moreover, such a minimal political advance was achieved after an extremely fraught campaign, with the progress of the legislation in the Scottish 
Parliament hampered by opposition parties and the Keep the Clause group - a coalition of religious groups, school boards and social conservatives. Indeed, the most prominent spokesman for Keep the Clause - millionaire businessman Brian Souter - used his wealth to fund a private referendum on the repeal and rallied a host of organisations to lobby against the Executive's plans, eventually forcing a statutory response which, whilst fully repealing Section 2a, added guidelines enshrining marriage as the preferred family unit. To fully understand these political outcomes, we must understand the ways in which issues of sexuality and equality become culturally meaningful as the subject of politics.

To this end, my research focused on the representation of the campaign to repeal Section 28 in the print media and the record of Parliamentary debates and committee hearings. There was no attempt at a comprehensive content analysis or any formal coding of the material. Rather, the aim was to identify exemplary discourses on both sides of the debate, within the cultural and political spheres, in order to delineate the ways in which equality is shaped as a cultural/political idea. The focus was therefore on the Parliamentary records and on two major newspapers; The Guardian, which is the most liberal national quality available in Scotland, and The Daily Record, which is Scotland's most popular tabloid paper. ${ }^{3}$ The Record spearheaded support for the 'keep the clause' campaign whereas the Guardian maintained its liberal support for repeal, and became directly critical of the Daily Record's position. They provide key illustrative examples of the types of discourses deployed on both sides of the debate and thus allow us to begin an initial exploration of the frameworks of meaning and explanation within which homosexuality, homosexual 'equality', morality and heterosexuality could be understood during this period. 


\section{Invalid Citizens}

In the Daily Record, there were a range of discourses which marginalized homosexual identities by emphasising their flawed 'nature' or their 'threat' to children. Whilst many of these pieces were presented as simple reports on the repeal campaign, the editorial stance of the paper was explicit advocacy for the Keep the Clause campaign, and so the reports can be understood as representational articulations of this position, drawing on pre-existing frameworks of meaning around homosexuality for their resonance. For example, in an attempt to deny that he is homophobic, the leader of the Keep the Clause campaign makes the association of homosexuals with people who are HIV positive: 'Last night, Souter declared: "It's just not the case we are homophobic. We've got homosexual friends, I've had people with HIV in my house'(Daily Record, 15.1.00 p6). This conflation of HIV status with homosexuality has been widely documented in both Britain and the United States, (Altman 1986, Weeks 1996) as a manifestation of the medical model of sexuality through which the homosexual identity was first brought into being (Foucault 1980, Weeks 1989), characterised as both physically degenerate/diseased and psychologically flawed. This articulation of homosexuality as 'unhealthy' is a consistent theme in the arguments against repeal: 'I am supposed to love my neighbour and I try to do that as much as I can, but I will not stand for this kind of behaviour which is now being regarded as wholesome and healthy (Cardinal Winning, reported in Daily Record, 18.01 .00 p6). Furthermore, an article written by Cardinal Winning setting out the case for retaining Section 28 argues: "Gay sex is wrong, because such behaviour is not good for the human person. Far from liberating a person, it ensares them in a lifestyle that can never respond to the deepest longings of the human heart"' (Daily Record,16.06.00 p8) 
'Gay sex' used to be biblically wrong, but here we have a Cardinal deploying a psycho-spiritual discourse to justify rejecting homosexual acts as damaging to 'human person(s)' The displacement of explicit religious doctrine with psychospiritual discourses is symptomatic of the importance attached to romantic love as the ultimate route to self-fulfilment which is evident in late modernity and based upon a recognition that traditional religious teachings are much less powerful in an increasingly secular world (Giddens 1991, 1992, Evans 1993). These constructions of homosexuality clearly draw upon essentialist divisions of legitimate/illegitimate sexual identities which dominate culture in the West but I suggest that they also serve to pre-empt political discourses of equality and rights. Rendering homosexuality as physically diseased and/or psychologically flawed is a depressingly familiar strategy in the explicit invalidation of lesbian and gay lives, but this is also an implicit invalidation of political capability - the basis of citizenship. Our liberal democratic settlement posits 'the individual as the basic unit in democratic life' (Phillips 1993:114) but that individual must be responsible and rational (Phillips 1993, Seidler 1989) - and constructions of a particular group as falling short of these conditions has often served to legitimise their political exclusion and/or their 'capability' to engage in decision-making, either for themselves or for the wider polity. Women, ethnic minorities, children, convicted criminals are some such examples, and the tenor of the more explicitly negative constructions of homosexuality suggests a similar implication, particularly in the perceived need to 'protect' children against the claims of homosexual citizenship.

Referring to the book Jenny Lives with Eric and Martin - whose presence in school libraries was used as the central example to justify the introduction of Section 28 in 
1986 - the example below quotes the Keep the Clause line of such material presenting a threat to children:

Neal Cavalier-Smith, publisher of Prowler Press, which owns the rights to the book, says he will rush out an updated version of the book if the Section is repealed..........campaigners against the repeal of the Section, led by Stagecoach tycoon Brian Souter, expressed dismay at the prospect last night. A spokesman for Keep the Clause said: "This is exactly what we have been warning of. It underlines the dangers to Scottish schoolchildren and this is why the campaign to keep Clause 28 is so vital to protect our children." (Daily Record, 25.01.00 p9)

This notion of protecting children from the threat of homosexuality is consistently reiterated in the press reporting:'The Archbishop of Canterbury yesterday entered the debate, insisting that Section 28 was a "“matter of concern" to him. Dr George Carey said: "With or without Section 28, we need to be sure that there are adequate safeguards in place for schools and pupils." (Daily Record,24.01.00 p2) and:

Campaigners lifting the ban on gay sex education in schools are targeting teachers and pupils with homosexual propaganda. One gay group at the forefront of the campaign to scrap Section 28 has published a leaflet urging schoolchildren to try gay sex. A group calling itself Avert offers a range of information for training teachers and school governors. The site suggests open discussions about homosexuality in class and offers links to other gay sites with instructions on gay sex practices. The Daily Record also discovered 
dozens of other websites with openly pornographic images masquerading as educational material. (Daily Record, 21.02.00, p.8)

[They mention three organisations Phace West, Gay Men's Health and Healthy Gay Scotland which are part publicly funded and apparently have websites with explicit sex acts (PW), guides on 'coming out' (HGS) public sex and buying porn and sex toys (EGMH).]

Here both homosexual acts and identity are taken for granted as undesirable but the main threat is actually one of suggestion; 'urging', 'propaganda', 'suggest' and 'offers...information'. Children are seen as open to suggestion, persuasion and propaganda, and are thus vulnerable to the acceptance of homosexuality as a normalised identity which, as Epstein notes, is a threat to the social privilege of heterosexuality (Epstein 2000). This draws on the many complex discourses surrounding childhood and sexuality: childhood as a time of 'innocence' as well as children as potentially unruly in that their sexuality needs to be monitored, controlled and moulded (Elias 1978, Moran 2001, Jackson 1990). This 'desire to protect' is precisely about protection from the 'promotion of homosexuality'. Although research demonstrates the genesis of the policy of Section 28 as a tactical and strategic tool to discredit metropolitan local governments and their socially liberal and fiscally redistributive agendas (Durham 1991), it is remarkable that the discourse of Section 28 remained stable as a set of ideas which takes for granted the notion that homosexuality can and will be promoted. This construction of a compulsive homosexuality which must have new recruits, resonates with understandings of lesbians and gays as excessively sexualised, unrestrained in their sexual behaviour and predatory, thus connecting a cultural circuit in which homosexuals are political 
invalids: slaves to their obsession with sex, without regard for their own physical and spiritual well-being, and unable to participate in the polity without threatening other fundamental, indeed, 'natural' rights, such as those of children to be protected from homosexuality.

\section{Hierarchies of Equality in Liberal Democracy}

Whilst I have suggested that the explicitly negative constructions of homosexuality during the repeal campaign serve to pre-empt discourses of equality and citizenship, it is undeniable that public political discourse has shifted to a position in which overt articulations of discrimination are less commonplace. Accordingly, supporters of Section 28 often focused on the threat to heterosexuality rather than the threat from homosexuality. This 'threat' was located within the context of a wider range of threats to traditional family values.

Betty Souter spoke out as it emerged that her husband plans a family values alliance to challenge politicians. "I have watched the introduction of a stream of measures designed to liberate our society which have undermined our traditional concept of family. Examples include quick divorces, legitimising illegitimacy, abolition of married couples allowance and the repeal of Section 28.' (Daily Record, 14.02.00, p.8)

The acceptance of homosexuality as equivalent to heterosexuality threatens the maintenance of gender divisions, as do divorce, unmarried parenting and the apparent lack of government policies to privilege marriage. We see homosexuals, at worst, being penalised as scapegoats and, at best, characterised as symptomatic of the loosening of the traditional familial bonds that were once responsible for binding us 
together as a coherent society: 'But [Souter] added: "We are still concerned that same sex relationships will be given moral equivalence with marriage". A spokesman for Cardinal Winning said: "There will be a backlash from Scottish parents. They will realise that Scottish children will have to make do with an 'anything goes' morality in the classroom"' (Daily Record, 17.03.00, p.8).

Clearly, moral equivalence is a defining issue for the Keep the Clause campaign, as it was for those groups who made submissions to the Local Government Committee who were delegated to consider the repeal during the second stage of its passage through Parliament. For example, the Bishops' Conference for Scotland argues that 'It should be noted that many groups who advanced the cause of homosexual rights are committed to promoting homosexuality as equivalent to heterosexuality' (SP paper, session 1) and 'We therefore argue that homosexual relationships cannot be presented as having the same moral equivalence to marriage. As such, sex education should be designed to value and support heterosexual marriage', From Keep the Clause (SP paper, session 1), with similar mentions of moral equivalency as unacceptable by the Christian Action Research and Education and the Conservative members of the committee. Previous research has shown that heterosexuality is often taken as the implicit norm in society with the relationship of domination/subordination to homosexuality often naturalised (Brickell 2001, Rahman 2000) and/or translated into 'heteronormative' conceptualisations of citizenship (Johnson 2002, Richardson 2000). In the Scottish example, there is an explicit focus on heterosexuality as the preferred norm; morally, socially and naturally, and also an explicit recognition that heterosexuality needs to be supported by institutional political technologies and values. 
All we are saying is in a climate where family life and social cohesion are constantly under pressure, children should at least be presented with a traditional model to which to aspire. Marriage rates may be down, divorces may be up but are we to assume the government consider these trends to be encouraged rather than resisted? (DailyRecord,leader comment, 31.05.00, p.8)

I do not mean to demean, stereotype, devalue or stigmatise those families that exist outwith marriage.....However, I believe that marriage is under attack from many quarters . To deny marriage its legal definition is, knowing or unknowingly, an attempt to devalue marriage....(Brian Monteith, Con, Mid Scotland and Fife, Col 971, Local Government Committee meeting 18, $30.5 .00)$

Although neither side in the debate actually suggested the legal reformulation of marriage (however, sensible that might be, Rahman 1998), the institution of marriage became the fixation of the Keep the Clause campaign, with demands that its social and moral desirability be institutionalised within sex education as a counter-balance to the removal of Section 2a. Thus, the hierarchies of morality which privilege a particular form of heterosexuality - expressed most completely in the institution of marriage - become the explicit translation matrix for hierarchies of political equality. I have argued before that liberal conceptualisations of equality often founder on the rock of essentialist moralities (Rahman 1998, 2000) and this recent example from Scotland supports this contention. Moreover, it suggests that there is an emergent public discourse of an explicitly defined hierarchy of political 'equality'or rights, 
which at one extreme encodes heteronormativity as the default state of 'equality' and, at the other extreme, explicitly calls for special rights for heterosexuality.

One of the ways in which these 'special rights' for heterosexuality is justified is precisely to draw upon the normalisation of heterosexuality within liberal democracies. In a convenient marriage of sexual hierarchies and democratic ideals, we see the deployment of democratic discourses of majority rule as another reason for keeping the clause, or at least, in-stating another legal support to marriage. When Brian Souter of the Keep the Clause campaign funded a private referendum on the issue of repeal, the results were held up as a democratic mandate for retention:

[Souter] said he was delighted at the $35 \%$ turnout in their referendum. $\mathrm{He}$ said "A denial of this result would be a denial of democracy"....Cardinal Thomas Winning...said "This result is a clear statement of the will of the Scottish people".

[Total ballots issued 3970712; total votes cast 1272202; total valid votes cast 1260846. Votes to retain Clause 28 1094440; votes to repeal 166406] (Daily Record, 31.05.00, p.8)

Democracy is understood here to be the 'will of the people'; democracy as a numbers game whereby the majority overrides the minority. This resonates with popular understandings of democratic procedures as equal enfranchisement - one person, one vote - and democratic outcomes as the results of majority expression through this vote. Even the consultation process undertaken by the Scottish Executive prior to the repeal is imbued with democratic discourses on both sides of the debate: 
Dewar and company refused to be bound by the results of the consultation, which they instigated, but he says: "We will certainly listen to it because that's what you do in a democracy". Ignoring the voice of the people because they say something that does not suit you is a strange way of 'listening'....The next six months will be dominated by an issue likely to offend the majority and confirm MSPs put their own politically correct agenda before the people's priorities.

(Tom Brown, conservative commentator, Daily Record 17.01.00, p.8)

Of course, the moral weight which democracy carries in the West is difficult to overstate, so inevitably all politics will be refracted through this lens if at all possible. But here we are seeing the reductive equation of democracy with majorities, precisely because the 'democratic' majority is assumed to be synonymous with the moral majority - heterosexuals - who will supposedly be offended by the repeal of Section 28. The results of the referendum funded by Souter for the Keep the Clause campaign, showed an overwhelming majority in favour of retaining Section 28 . This gave further ammunition to the majoritarian discourse, despite the poor turnout and methodological criticisms of the referendum process. So who are this majority? One of the interesting aspects of the campaign is that whilst they were constructed as the norm - democratically and morally - they were also largely portrayed as silent:

[Cardinal Winning said] "What pains me is that the silent majority are so silent that the silence is deafening. I wish to God they would speak up. But when you do say something about it, you are accused of homophobia which is absolute rubbish...(Daily Record,18.01.00, p.6) and Which of our MSPs will 
have the courage of their convictions? Which one will speak for the people? (Daily Record leader comment, 13.05.01, p.8)

Clearly it would not suit those campaigning to keep the clause to consider the possibility that the 'deafening' silence of the majority was simply an indication of their lack of interest, or even of their support for the repeal. Rather the 'majority' seem to be silent because they are powerless in the face of a political class and minority group who are vocal and determined. Lesbian and gay groups were described in terms which invoke negative aspects of both sexual identity and morality and, crucially democratic processes and values: 'After all, they have already allowed pressure groups to use public funds to promote homosexual practices under the guise of health promotion using council and health board budgets..' (Brian Souter, in Daily Record, 25.01.00, p.8) and 'Cardinal Winning's controversial suggestion last month, that there is an international lesbian and gay plot to destroy the family was hardly his own invention; it lies at the heart of the Vatican sexual ideology' (The Guardian 16.02.00). Thus, the democratic and moral majority is under threat, from both lesbian and gay 'perverts' who are putatively conspiring internationally, and operating as 'pressure' groups aided by a political class who ignore the 'will of the people' in order to promote 'politically correct propaganda'.

This is the flip-side of the 'good' democratic discourse; the perversion of true democratic ideals and processes by special interests allied to an unresponsive political elite in thrall to their own version of ideals - the extremism of political correctness. The arguments for repeal are rendered illegitimate, not simply because they challenge hetero-morality, but because they are also undemocratic: against the majority will and forced through by special interests who have disproportionate influence on political 
processes. Alternatively, repeal can be tolerated as long as moral equivalence is not conceded, and the best guarantee of maintaining this inequality is a further institutional repsonse, enshrining marriage in the sex education guidelines. Either way, the shape of equality is hierarchical, with different 'qualities' of equality reserved for dominant and subordinate groups.

\section{Equal Rights as the Winning Formula}

Although I have argued that the repeal campaign was rendered illegitimate in democratic terms, there were certainly attempts to frame it within the discourses of equal/human rights and these appear - unsurprisingly - more consistently in the paper which supported repeal:

[Donald Dewar] said the serious argument over Section 28 could not be 'reduced to irresponsible scaremongering on advertising hoardings.' He said the argument should be conducted on 'facts, not on nameless fears.' Speaking with vigour, Dewar said: "Section 28 is discriminatory. It is seen as offensive. It is not a necessary safeguard and that is why it should go.' (Alex Bell "Dewar barrage on Section 28" 12.3.00 in The Guardian)

Solicitors Belmont Hodgson found the Section.....breaches the right to freedom of expression and to privacy and respect for family life. Both are enshrined as articles 10 and 8 in the European Convention on Human Rights, which will be incorporated into British law on October 2.....Goaded by $\mathrm{Mr}$ Hague to drop 'politically correct propaganda', the Prime Minister hit back. "The truth of the matter is that this campaign (against Section 28 repeal) is 
based on people who don't want to come out and say they are prejudiced against gay people and so they hide behind the issue of child protection". (Lucy Ward, "Section 28 violates Human Rights Act, lawyers claim”, in The Guardian, 30.03.00)

These discourses of anti-discrimination also appear regularly in the Parliamentary debates: '..the legislation has helped to perpetuate a climate of intolerance...'(SP paper 89, session 1 -submission from the Stonewall Youth Project to committee stage); '..we do not honour marriage and the family by denying the reality of other relationships that are now established in today's society...'(Wendy Alexander, Minister for Communities, Ethical Standards in Public Life Bill, first stage, 27.4.00, col 88-89); 'the legislation is socially exclusive and contrary to everything the executive and councils are trying to achieve together.'(SP paper 89, session 1submission from SOLACE [local govt assoc) to committee stage). Furthermore, there is some evidence of a discourse of equivalence, or at least recognition of difference, and social inclusion in these examples and in the ones below.

When we teach children in schools about religious and cultural differences, we assume that we are promoting ...understanding and tolerance. How is this different from teaching them to understand the differences in sexual orientation which are part of life. (Parents Enquiry Scotland, SP paper 1, submission to Local Government committee)

I have great respect for marriage. I respect equally lone-parent families, grandparents who bring up their grandchildren, same-sex families, foster carers and the carers of children in residential homes or schools. Whatever 
the type of family situation I respect it if it provides happiness and security and allows a child to reach their full potential. (Kate MacLean[Dundee West, LAB] Col 109, first stage debate, 27.4.00)

Given the dominance of anti-discrimination discourses in the Parliamentary debates and among liberal press advocates of repeal, it is not surprising that those favouring retention of the clause do not simply dismiss equal rights/non-discrimination. Rather, the strategy is to override equal rights with a characterisation of repeal as 'special rights' for a group way down the moral and democratic hierarchy: specifically the right to promote a particular version of lifestyle and morality. Thus the basic negative liberty of repeal becomes framed as a positive liberty to 'promote':

$\ldots 83 \%$ of people in Scotland were tolerant of homosexuals and thought that the subject should be discussed in schools - I agree with them. The same survey showed two-thirds did not want the promotion of homosexuality in our schools - I agree with them. When will our politicians realise the difference between tolerance and license?

(Brian Souter, in the DailyRecord, 25.01.00, p.8)

The repeal of section 28 is not characterised as a move towards 'equality', but rather as a move beyond equality to 'special rights', the license to 'promote', which is undemocratic in that it is anti the (hetero-moral) majority. Moreover, homosexuals are characterised as already having 'equal rights', even though in the same breath those rights are conjoined with a limited settlement of equality; one which does not undermine heterosexual privilege: 
...But I am not going to allow that name-calling to put me off fighting what I see as a very important issue for my children. I do not condemn homosexuals, I respect them as individuals and I respect their rights...

....I believe homosexuals should have equality of opportunity. I fully supported the acceptance of gays in the armed forces. But what happens between adults, how they live their lives is one thing. What we teach children in schools is something else."

(Brian Souter in the Daily Record, 15.01.00)

Section 28 will not prevent the objective discussion of homosexuality in the classroom, nor will it prevent the counselling of pupils who are concerned about their sexuality... The evidence from down South is that material was available that, in the absence of Section 28, might have been advanced for circulation - no one has illusions of that material or the intentions of certain bodies circulating it. (Annabel Goldie, West of Scotland, CON, Col 97-98, Ethical Standards in Public Life Bill, Stage 1, 27.4.00)

Equal rights discourse as a route to non-discrimination was both successful (in that the section was finally repealed) and unsuccessful (in that another policy was added which privileged an institution which, by definition, excludes lesbians and gays). Rather than a winning formula, it is more the result that the late Cardinal would probably be happy with; 'equal' rights which have been contested from multiple vectors to distort the shape of abstract, universal 'equality' into a mould which supports institutionalised heterosexuality.

\section{Conclusion}


Whilst the examples presented here are not illustrative of a comprehensive content analysis, my aim was not to document instances of the representations of homosexuality. Rather, I took as given that the campaign to repeal Section 28 would be quantifiably significant and sought instead to consider how the innumerable representations related to political questions of equality and citizenship. First, I suggest that the most negative public and political discourses on homosexuality continue, in Scotland at least, to be framed in ways which sustain the stigmatisation and marginalisation of lesbian and gay identities. Homosexuals are represented as, above all, threatening; a sexual threat to children, a threat to institutionalised heterosexuality, a threat to the 'correct' gendered socialisation of children and, finally, a threat to the 'democratic' majority. These threats are constructed to either pre-empt claims to equality through the invalidation of citizenship status, or they are used to characterise homosexual equality as 'special rights'. Second, the hierarchies of morality which underpin essentialist constructions of gender/sexuality remain all too evident in contemporary discussions and are similarly mobilised to raise the spectre of the moral and physical corruption of children and to delegitimise the drive for equal rights for lesbians and gays.

The condition of equality achieved is therefore somewhat suspect, with Section 28 repealed but recuperated through statutory guidelines in sex education which advocate marriage. The shape of equality is therefore contorted to confirm institutionalised (and outdated) forms of heterosexuality as both the blueprint for social citizenship and deserving of special rights. Nonetheless, the Parliamentary debates do signal a contested understanding of 'equality' with both a recognition of the transformations in heterosexuality (specifically family forms) and the need to recognise diversity as a matter of democratic principle. This suggests that whilst we 
are right to interrogate liberalism as 'democratic shell' for heterosexism, we should also consider the ways in which this discourse contains conceptualisations of equality as diversity within its precepts (Phillips 1993). The clamour over the repeal of Section 28 can be explained as reformulations of new right values (Waites 2000), moral panics (Wise 2000) and, as I have suggested here, the reaffirmation of institutionalised heterosexuality. However, it can also be understood as a debate over equality and citizenship which has been provoked in part by the explicit recognition of the cracks in hegemonic heterosexual institutions. Whilst liberal democracy serves to shelter a moral and social order based on heterosexism, changes in the institutional and experiential forms of heterosexuality throw up simultaneous challenges to liberal notions of equality and citizenship. This is only tantalisingly evidenced here, and so my claims are not conclusive but merely suggestive, but even given the limited condition of equality achieved in the Scottish example, perhaps it is possible to discern the discursive resource of equality being reformulated and re-shaped to mean something more than heterosexual privilege. 


\footnotetext{
${ }^{1}$ I will use the terms lesbian and gay although I recognise that they are contested and exclusionary. However, the debates around Section 28 referred almost exclusively to 'lesbians' and 'gays' rather than any other terms.

${ }^{2}$ The constitutional set-up both within the UK and in relation to the EU is somewhat unresolved. Although the Scottish parliament has been given independence in a number of areas which have traditionally been separately dealt with by the UK parliament through the Scottish Office (education, law, health, local government), the constitutional situation is that the UK parliament in London retains legal authority over a number of issues.. This is therefore not an explicitly federal system with a precise separation of powers. The same blurring of responsibilities and authority is evident in the ongoing development of the EU although harmonisation of policies is tipping the balance towards EU institutions (see Bell 1998 on anti-discrimination policy). A ruling in November 2002 by the Appeal Court used the newly incorporated Human Rights Act (1998) to reword an Act of Parliament to allow tenancy rights for same sex couples. It is suggested that this ruling will have wider implications for social policy (The Guardian, November $6^{\text {th }}$ 2002) but note that it took domestic legislation to allow for compliance with the European Convention.

${ }^{3}$ Parliamentary debates were accessed through the parliamentary websites. The papers were analysed over the period of the repeal campaign - six months from January 2000 to June 2000 for articles reporting the Scottish Executive's proposed repeal of Section 28. This identified 77 'section 28' stories. Circulation figures from the Audit Bureau of Circulation for this period are 620,103 for the Record and 396,534 for the Guardian (although this is UK wide rather than Scotland).
}

\section{References}

Altman, D (1986) - Aids and the New Puritanism. London: Pluto Press.

Bell, M. (1998) - "Sexual Orientation and Anti-discrimination policy: the European

Union." in Carver, T. \& Mottier, V. (eds), Politics of Sexuality. London: Routledge. Brickell, C (2001) - "Whose 'Special Treatment'? Heterosexism and the problems with Liberalism." in Sexualities, vol 4 no 2.

Carabine, J. (1996) - "Heterosexuality and Social Policy" in Richardson, D. (ed.)

Theorising Heterosexuality. Buckingham: Open University Press.

Durham, M. (1991) - Sex \& Politics: The Family and Morality in the Thatcher Years. London: Macmillan

Elias, N. (1978) - The Civilising Process, Volume One. Oxford, Blackwell. Epstein, D (2000) - "Sexualities and Education: Catch 28" in Sexualities, Vol 3 no 4 Evans, D.T. (1993) - Sexual Citizenship; the Material Construction of Sexualities. London: Routledge.

Fraser, N (1998) - 'Heterosexism, misrecognition and capitalism: a response to Judith Butler.' New Left Review, no. 228 
Giddens, A. (1991) - Modernity and Self Identity: Self and Society in the Late Modern Age. Cambridge: Polity Press

Giddens, A. (1992) - The Transformation of Intimacy. Cambridge: Polity Press.

Jackson, S. (1990) - "Demons and innocents: Western ideas on children's sexuality in historical perspective" in Perry, M. E. (ed.)Handbook of Sexology, Vol. 7: Childhood and Adolescent Sexology. Elsevier Science Publications.

Johnson, C (2002) - 'Heteronormative citizenship and the politics of passing.' In Sexualities, vol. 5 , no. 3

Moran, J (2001) - "Childhood Sexuality and Education: The Case of Section 28" in Sexualities, Vol. 4, no. 1.

Phelan, S. (1997) - "Introduction" in Phelan, S. (ed.) Playing with Fire: Queer

Politics, Queer Theories. New York: Routledge

Phillips, A. (1993) - Democracy and Difference. Cambridge: Polity Press.

Plummer, K. (1995) - Telling Sexual Stories: Power, Change and Social Worlds.

London: Routledge.

Rahman, M (1998) - 'Sexuality and Rights: problematising lesbian and gay politics.'

In Carver, T. \& Mottier, V. (eds), Politics of Sexuality. London: Routledge.

Rahman, M (2000) Sexuality and Democracy: Identities and Strategies in lesbian and gay politics. Edinburgh: Edinburgh University Press.

Rahman, M. \& Jackson, S. (1997) - "Liberty, Equality and Sexuality: Essentialism and the Discourse of Rights." in The Journal of Gender Studies, Vol., 6, no. 2.

Reinhold, S. (1994) - "Through the Parliamentary Looking-Glass: Real and 'Pretend' Families in Contemporary British Politics" in Feminist Review, No. 48.

Richardson, D. (1998) - "Sexuality and Citizenship." in Sociology, Vol. 32, No. 1.

Richardson, D (2000) "Claiming Citizenship? Sexuality, Citizenship and

Lesbian/Feminist theory" in Sexualities, Vol 3 no. 2 pp255-272

Seidler, V (1989) - 'Reason, desire and male sexuality.' In Caplan, P (ed), The

Cultural Construction of Sexuality. London: Routledge.

Stychin, C (1998) - A Nation by Rights: National Cultures, Sexual Identity Politics

and the Discourse of Rights. Philadelphia: Temple University Press.

Thomson, R (1993) "Unholy Alliances: the Recent politics of Sex Education" in

Bristow, J and Wilson, A (eds) Activating Theory: Lesbian, Gay and Bisexual

Politics. London: Lawrence and Wishart.

Waites, M. (2000) - 'Homosexuality and the new right: the legacy of the 1980s for new delineations of homophobia.' Vol 5, No. 1, Sociological Research Online

Walby, S (1994) - 'Is Citizenship gendered?' in Sociology, vol. 28, no. 2

Weeks, J (1989) - Sex, Politics and Society ( ${ }^{\text {nd }}$ Edition). London: Longman.

Weeks, J. (1996) - Invented Moralities: Sexual Values in an Age of Uncertainty.

Cambridge: Polity Press.

Wise, S (2000) - "'New Right" or "backlash"? Section 28, moral panic and 'promoting homosexuality'. Vol 5, No. 1, Sociological Research Online Young, I.M. (1989) - "Polity and Group Difference" in Ethics, Vol. 99, No. 2, pp250274.

Young, I.M (1994) - 'Gender as seriality: thinking about women as a social collective.' Signs, vol. 19, no.3 